Japan. J. Med. Sci. Biol., 40, 75-78, 1987.

Short Communication

\title{
EVIDENCE FOR INFECTION CAUSED BY SPOTTED FEVER GROUP RICKETTSIA IN KYUSHU, JAPAN
}

Seigo YAMAMOTO, Norihiko KAWABATA, Tsuneo UCHIYAMA1 and Takahiro UCHIDA1

Miyazaki Prefectural Public Health Laboratory, Kitatakamatsu-cho, Miyazaki 880 and 1Department of Virology, School of Medicine, The University of Tokushima, Kuramoto 3, Tokushima 770

(Received June 1, 1987. Accepted July 13, 1987)

SUMMARY: Of 50 cases that gave negative immunofluorescence reaction with Rickettsia tsutsugamushi among patients with suspected tsutsugamushi disease encountered in Miyazaki Prefecture during the last four years, three showed a significant rise in the antibody titer to Rickettsia montana, a species of spotted fever group. This paper reports evidence for the occurrence of the rickettsial infection of the spotted fever group in Kyushu, Japan.

Tsutsugamushi disease is a major rickettsial infection existing in certain areas that extend from the northern part of Honshu to the sourthern part of Kyushu, Japan (Fig. 1). During the last four years (1982-1986), 429 specimens of sera from patients with suspected tsutsugamushi disease were sent to the Miyazaki Prefectural Public Health Laboratory in Miyazaki-city located in the southern part of Kyushu, and 320 patients were confirmed as tsutsugamushi disease by the specific immunofluorescence (IF) test. In Shikoku which lies to the east of Kyushu, on the other hand, only two cases of tsutsugamushi disease were reported during the last decade (1), though the reason for the low incidence is unclear.

山本正悟・川畑紀彦 (宮崎県衛生研究所 宮崎市北高松町5-30)

内山恒夫·内田孝宏 (德島大学医学部ウイルス学教室 德島市蔵本町3) 


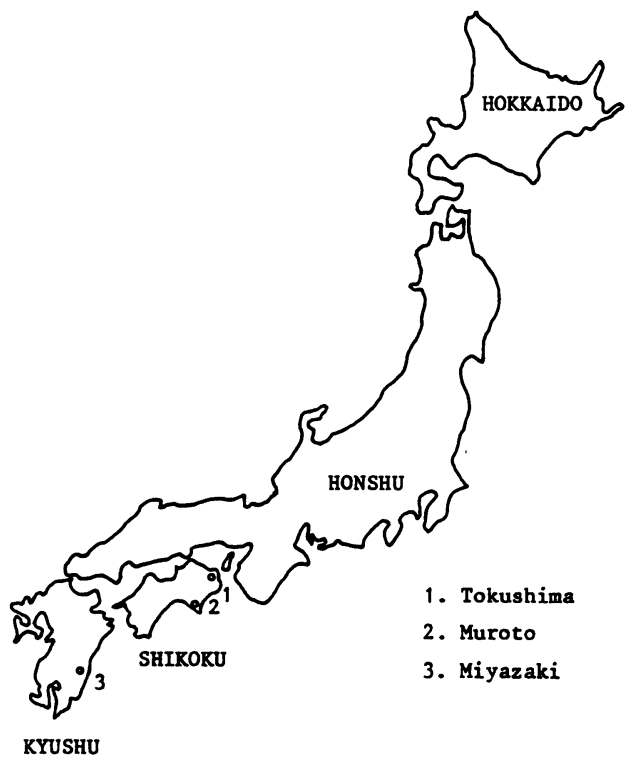

Fig. 1. Map of Japan.

Recently, rickettsial infections with the spotted fever group (SFG) have been found along the southeastern coast of Shikoku (2-4). The causative agent was isolated from the blood of patients in the Muroto area, the southern end of the southeastern coast of Shikoku (5). The reported cases of the infection were confined to the southern part of Shikoku, where the climate is temperate and warm and sustains sporadic subtropical vegetation like that of the southern part of Kyushu. One of the authors (Ta. U.) suspected that the spotted fever might have occurred in the southern part of Kyushu, because of its incidence in Shikoku. Thus, we intended to test the sera that gave negative IF reaction with Rickettsia tsutsugamushi. Among the paired sera of 50 patients, three showed a significant rise in the antibody titer to $R$. montana, a species of SFG that reacted with the sera from patients with the spotted fever in Shikoku (6) (Table I). Symptoms and signs of these three cases were similar; high fever, generalized erythematous rash and an eschar. Two cases were treated with Minocycline, followed by prompt defervescence. From the findings, the three cases with negative serologic reaction of tsutsugamushi disease were the rickettsiosis of SFG. The present communication provides evidence for occurrence of the rickettsial infection of SFG in Kyushu. 
Table I. Antibody titers to the SFG antigen of patients' sera that gave negative immunofluorescence reaction with Rickettsia tsutsugamushi

\begin{tabular}{|c|c|c|c|c|c|c|c|}
\hline \multirow{3}{*}{ Casea) } & \multirow{3}{*}{$\begin{array}{l}\text { Days } \\
\text { of } \\
\text { illness }\end{array}$} & \multirow{3}{*}{$\begin{array}{l}\text { Immuno- } \\
\text { globulin } \\
\text { classb) }\end{array}$} & \multicolumn{4}{|c|}{ IF titersc) to } & \multirow[b]{3}{*}{ Kawasaki } \\
\hline & & & \multirow{2}{*}{$\frac{R . \text { montana }}{\text { VR611 }}$} & \multicolumn{3}{|c|}{ R.tsutsugamushi } & \\
\hline & & & & Karp & Kato & Gilliam & \\
\hline \multirow{4}{*}{ M. A. } & \multirow[t]{2}{*}{8} & $\operatorname{IgM}$ & $\langle 20 \mathrm{~d})$ & $\langle 20$ & $\langle 20$ & $\langle 20$ & $\langle 20$ \\
\hline & & IgG & $\langle 20$ & $\langle 20$ & $\langle 20$ & $\langle 20$ & $\langle 20$ \\
\hline & \multirow[t]{2}{*}{23} & IgM & 320 & $\langle 20$ & $\langle 20$ & $\langle 20$ & $\langle 20$ \\
\hline & & IgG & 640 & $\langle 20$ & $\langle 20$ & $\langle 20$ & $\langle 20$ \\
\hline \multirow{4}{*}{ K. K. } & \multirow[t]{2}{*}{5} & IgM & $\langle 20$ & $\langle 20$ & $\langle 20$ & $\langle 20$ & $\langle 20$ \\
\hline & & IgG & $\langle 20$ & $\langle 20$ & $\langle 20$ & $\langle 20$ & $\langle 20$ \\
\hline & \multirow[t]{2}{*}{21} & IgM & 1280 & $\langle 20$ & $\langle 20$ & $\langle 20$ & $\langle 20$ \\
\hline & & IgG & 10240 & $\langle 20$ & $\langle 20$ & $\langle 20$ & $\langle 20$ \\
\hline \multirow{4}{*}{ T. Y. } & \multirow[t]{2}{*}{11} & IgM & 40 & $\langle 20$ & $\langle 20$ & $\langle 20$ & $\langle 20$ \\
\hline & & IgG & 160 & $\langle 20$ & $\langle 20$ & $\langle 20$ & $\langle 20$ \\
\hline & \multirow[t]{2}{*}{27} & $\operatorname{IgM}$ & 160 & $\langle 20$ & $\langle 20$ & $\langle 20$ & $\langle 20$ \\
\hline & & IgG & 1280 & $\langle 20$ & $\langle 20$ & $\langle 20$ & $\langle 20$ \\
\hline
\end{tabular}

a) M.A., female, 43 years old, onset on October 19, 1983; K.K., male, 72 years old, onset on June 15, 1985; T.Y., male, 68 years old, onset on April 11, 1986.

b) FITC conjugated goat anti-human IgM (mu-chain) and IgG (gammachain) antibodies (TAGO Inc., Burlingame, CA, USA) were used in the indirect IF test.

c) Preparation of antigens for $R$. montana and $R$. tsutsugamushi was described elsewhere (see references 6 and 7, respectively).

d) The figures are the reciprocals of titers.

\section{ACKNOWLEDGEMENTS}

The authors are grateful to Dr. Yoichi Minamishima, Department of Microbiology, Miyazaki Medical College, for his interest and encouragement during this study. 


\section{REFERENCES}

1. Suto, T. (1986): Virus, 36, 55-70 (in Japanese).

2. Uchida, T., Mahara, F., Tsuboi, Y. and Oya, A. (1985): Japan. J. Med. Sci. Biol., 38, 151-153.

3. Mahara, F., Koga, K., Sawada, S., Taniguchi, T., Shigemi, F., Suto, T., Tsuboi, Y., Oya, A., Koyama, H., Uchiyama, T. and Uchida, T. (1985): J. Japan. Assoc. Infect. Dis., 59, 1165-1171 (in Japanese).

4. Uchida, T., Tsuboi, Y., Oya, A., Funato, T. and Kitamura, Y. (1986): J. Japan. Assoc. Infect. Dis., 60, 49-52 (in Japanese).

5. Uchida, T., Tashiro, F., Funato, T. and Kitamura, Y. (1986): Microbiol. Immunol., 30, 1323-1326.

6. Uchida, T., Tashiro, F., Funato, T. and Kitamura, Y. (1986): Microbiol. Immunol., 30, 1061-1066.

7. Yamamoto, S. (1984): Clin. Virol., 12, 270-274 (in Japanese). 